article outlines the general principles of the presented approach based on involuntary memorisation which is opposed to the voluntary one. The author substantiates the choice of proverb-type phraseological units (PTPU) as the material of the study arguing that the said units provide favourable conditions required for the involuntary memorisation efficiency, such as vivid emotional background, students' active involvement and their interest which may contribute to the successful development and retaining of the corresponding valeological notions and beliefs. The paper contains some examples out of the selected 300 PTPU in eight notional categories (ranging from the 'healthy way of life' and 'money can't buy you health' to 'don't worry, be happy') that may play an essential role in the valeological culture development while teaching English to schoolchildren. The author presents his arguments in favour of translation, being a hermeneutic activity, to be used as the main tool to accomplish tasks related to the selected material. The paper provides the results of the original experiment which proved that the tasks offered to the subjects stimulated their creative and mental activities, as well as contributed to the formation of their positive attitude towards the learning process. According to the results obtained through the subjects' questioning, the average indicator of their positive attitude amounted to 4.5 out of 5,0 maximum possible.

Keywords: active learning, creative activity, experimental research, English phraseological units, involuntary memorisation, mental activity, schoolchildren, teaching foreign languages, translation, positive attitude, valeological culture development.

Подано до редакиіï 17.10.2016

UDC: $37: 347.191 .11(73)$

\author{
Iryna Lytovchenko, \\ PhD (Candidate of Pedagogical Sciences), associate professor, \\ Department of English for Engineering, \\ National Technical University of Ukraine "Kyiv Polytechnic Institute", \\ 37, Peremohy Ave., Kyiv, Ukraine
}

\title{
DEVELOPMENT OF HIGHER EDUCATION-INDUSTRY PARTNERSHIP AS FACTOR OF CORPORATE EDUCATION EFFICIENCY IN THE USA
}

The author aims to examine the specific features of development of partnership between higher education and industry in the United States of America, define its objectives, forms and mechanisms of implementation. The partnership emerged as a means of narrowing the gap between education and the labor market in the context of rapid development of science and technology, changes in the employment sphere and the need to provide the competitiveness of companies and the national economy. The active support of the federal government for over a hundred years helped create an institution of higher education-industry partnership manifested in a variety of forms and realised through a variety of mechanisms, which contributes to the modernisation of the corporate education in the US, knowledge creation and development, promotion of technologies, development of new products and services.

Keywords: higher education-industry partnership, forms of higher education-industry partnership, higher education institutions, industry, corporate education in the US.

Cooperation of the industrial sector with universities in the United States has been developed for more than a century, but only the transition to the knowledge economy made it really large-scaled and varied in modes. Research universities, business and government are working on joint initiatives to create and develop innovative forms of partnerships between education and industry, thus contributing to powerful knowledge development, narrowing a gap between the education sector and the marketplace, solving complex social problems and accelerating the economic growth of the country.

Various aspects of social partnership in education were studied by a number of scientists including: C. Alsanian, P. Valentine, G. Edmondson, R. Cervero, L. Lukianova, N. Nychkalo, O. Ohiienko, N. Patsiura,
H. Smith and others. However, the problem of specific features of its implementation in the United States requires further study.

With this in mind, the purpose of this article is to analyze the main steps in the development of the institute of higher education-industry partnership as a factor of effectiveness of corporate education in the United States, identify its forms and mechanisms of implementation.

Based on the interdisciplinary and systemic approaches to our research, we used a set of interrelated theoretical methods: comparative, structural, systemicfunctional analysis, comparison and synthesis, which are necessary for studying works of scientists, business literature, legal documents, and statistical data. 
The partnership between education and industry is commonly perceived as cooperation of companies and higher education institutions to provide training for employees in the fields that contribute to achievement of the mission and goals of the organisation. This partnership, which may be formal and / or informal, turns strengths, expertise and experience of both corporations and higher education institutions into the capital [3].

The social partnership in education is also recognised as a factor of the effective development of various sectors of education, especially vocational education, which should be perceived as interaction between educational institutions and economic agents to improve the efficiency of vocational education and meet the demands for skilled and competent labor force [9].

The corporate sector develops partnerships with educational institutions with certain purposes. The National Science Foundation identifies five reasons that encourage businesses to develop partnerships with universities: 1) to meet the needs associated with management of the enterprise, manufacture of products and provision of services; 2) to gain access to staff in areas where talents are rare, such as computer science, engineering, etc. 3) to improve staff training and development; 4) to minimise the expenditure on research; 5) to get the opportunity of carrying out the researches supported by the federal government [7, p. 23]. Business uses partnerships as an effective mechanism of corporate education development, which expands the knowledge base, secures effective investment in the human capital, contributes to the creation of new high-tech industries, promotion of technologies, development of new products and services.

Higher education institutions pursue their own aims when implementing partnerships with businesses. Among them are: 1) provision of a regular stream of income to the institution; 2) involvement of students in research of real business problems; 3) improvement of training programs with the view of the fact that a growing number of graduates go to work in business; 4) avoiding the painstaking and lengthy bureaucratic procedures necessary for receiving grants from the federal government; 5) work on complex research projects that are a priority for society; 6 ) access to equipment and research facilities of the companies [7, p. 25]. By partnering with business, higher education institutions are able to develop innovative curricula, enhance networks between the academic and business communities, meet the educational needs of the private business [5].

Scientists single out different forms of partnership between education and business. Heather Smith, for example, [10] identifies: engagement of business executives in boards of trustees of educational institutions; assistance of faculty in the development and teaching of educational programs in corporations; provision of corporate programs in higher education institutions with necessary equipment and the latest technologies by corporations; practice and internship of students and their further employment in corporations; cooperation between business and educational institutions in conducting research funded by businesses; grants for employee training, and others.

Other scientists, for example, Nell Eurich [4], identifies such forms of partnership as exchange programs for teachers, counseling of teaching staff, joint research projects, training managers, customised non-degree corporate programs, common educational facilities, practice and internship in corporations, on-the-job training, exchange of information and consulting services, charity.

The Council on Governmental Relations [2] defines six basic mechanisms of scientific cooperation between universities and companies:

- direct funding of university researches by companies as the most common form of scientific cooperation;

- partial funding by the federal government of joint research conducted by universities and companies;

- work of groups of companies and universities on various joint research projects in the area of common interests;

- licensing of university patents (usually resulting from research funded by the federal government) to companies for commercial use;

- start-up companies created with the involvement of university staff and having access to university facilities;

- exchange of research materials based on agreements between universities and companies.

Among the socio-economic factors of partnership in education are the profound changes taking place in the field of labor and employment, the need to address economic problems and maintain the competitiveness of enterprises and the national economy during the rapid development of science and technology; the need for continuous training of adults to meet the changing demands of the labor market. In this context, social partnership is perceived as a means of resolving conflicts between education and the labor market, a mechanism for development and proper functioning of the system of adult education [9].

The first step in the initiation of partnership between corporations and institutions of higher education was the adoption of the Morrill Act in 1865, which created the conditions for the establishment of agreements on cooperation between industry and higher education and helped transform the agrarian economy into the industrial one. At that time, higher education institutions started to teach people of different social backgrounds, not just the privileged classes to meet the needs of the industrial economy for skilled workers. Throughout the last century, the links between higher education and business were very close, but they periodically strengthened or weakened according to the competing interests of the federal and state governments, educational and business leaders [8].

Powerful government support of partnerships between business and education began with the adoption in 1948 of the Servicemen's Readjustment Act, also widely known as the G. I. Bill, aimed primarily to assist World War II veterans in adjusting to civilian life. This law ensured access to higher education to students who left 
school some time before and started college or returned to it after a certain interval.

In 1965, the federal financial support of working students was initiated by the Higher Education Act, which granted special scholarships and loans for their education. The next step which opened more access to training was the adoption of Pell Grant in 1970 which was a subsidy provided for college students with limited financial resources. Due to the federal Pell Grants, the enrolment of working students in higher education institutions greatly increased and those institutions initiated evening training programs and departments of continuing education to meet the needs of this group of students. The scope and functions of these departments have significantly grown with time and now they deal with continuous and professional education, corporate relations, human resources development, establishment of partnerships with business, creation and teaching of corporate programs.

The federal support of the fundamental research began during World War II. Until that time most of research was carried out at universities of Europe. In the United States, it was mainly conducted in corporate research laboratories. But in wartime, the federal government started to allocate significant funds to finance university research and after the war Vannevar Bush, Science Advisor to Presidents Franklin Roosevelt and Harry Truman, urged the Government to continue federal investments in it. His report "Science, the endless frontier" was crucial for the creation of the National Science Foundation [1].

The large scaled federal funding of university research began after the Soviet Union launched the first earth satellite in 1957. In the period from 1960 to 1966 the federal spending on research activities not related to defense, rose by six billion dollars and reached 35 billion dollars annually. Since 1966 these expenses have been cut but they have never been less than twenty billion dollars yearly [6].

The next important step taken by the government was the adoption of the Bayh-Dole Act in 1980, which not only solved a major problem of a lack of national policy on support of university research, but also allowed universities to retain the right for patents resulting from researches funded by the federal government, thereby encouraging universities to cooperate with the industrial

\section{ЛIТЕРАТУРА}

1. Bush V. Science, the endless frontier : A report to the President / Vannevar Bush. - Washington, D.C. : United States Government Printing Office, 1945. -184 p.

2. Council on Governmental Relations. Review of University-Industry Research Relationships. Washington, D.C. : CGR, 1996.

3. De la Garza G. F. Team up : Higher education business partnerships in North America : Understanding the differences (Working Paper No. 7) / De la Garza G. F., Landrum B. A., Samuels B. - New York, NY : Ford Foundation, 1997. - 78 p.

4. Eurich N. P. Corporate classrooms : The learning business / Nell P. Eurich. - Princeton. N.J. : Carnegie sector and make profits of university inventions. It brought about forty billion dollars of investment in the US economy in 1999 [2].

Since the adoption of the Bayh-Dole Act, significant changes have taken place in the country. In the early 1980's the United States began to develop its competitiveness actively on the global market and higher educational institutions were in the forefront of this process. At the Business-Higher Education Forum on Cooperation between Business and Higher Education, the Federal Reserve Chairman Alan Grinspan said that in modern globalised world, where growth prospects largely depend on the ability of countries to develop and use technology, American universities are envied around world. Benefits, such as the creation of new knowledge, new products, start-up companies are impressive. The rate of university research funded by the industrial sector is impressive as well. For example, the spending on this kind of research in 1997 was seven times greater than in 1970 [6]. An important form of promotion of university-industry partnership at present is the initiation by the federal government of special programs that require cooperation between universities and companies and their cost-sharing in the joint researches.

In summary, the results of our study give reasons to conclude that the partnership between industry and education emerged as a means of narrowing the gap between the education and the labor market in the context of rapid development of science and technology, changes in demands of labor market and the need to maintain the competitiveness of companies and the national economy. The active federal support for over a hundred years helped create a strong institution of education-industry partnership manifested in a variety of forms and realised through a variety of mechanisms, which contributes to the modernisation of the corporate education in the US, creation of new knowledge, promotion of technologies, development of new products and services.

Among the prospects for further research is the study of factors that foster the development of partnerships between universities and industry in the United States and also the analysis of possible barriers to such collaboration.

Foundation for the Advancement of Teaching, 1985. -163 p.

5. Fenwick D. C. Guide to campus-business linkage programs : education and business prospering together / Dorothy C. Fenwick. - New York : Macmillan, 1986. $278 \mathrm{p}$.

6. Hasselmo N. Working together, creating knowledge : The university-industry research collaboration initiative [Електронний ресурс] / N. Hasselmo. 2001. - Режим доступу : http://www.bhef.com/sites/g/files/g829556/f/report_2001 _working_together.pdf 
7. Higher education in partnership with industry / D. R. Powers, M. F. Powers, F. Betz, C. B. Aslanian. San Francisco : Jossey-Bass, 1988. - 367 p.

8. Kerr C. Higher education cannot escape history : Issues for the twenty-first century / Clark Kerr. - Albany, N.Y. : State University of New York Press, 1994. - 248 p.

9. Огієнко О. І. Тенденції розвитку освіти дорослих у скандинавських країнах : монографія / O. I. Огієнко. - Суми : Еллада-S, 2008. - 444 с.

\section{REFERENCES}

1. Bush, V. (1945). Science, the endless frontier: A report to the President. Washington, D.C.: United States Government Printing Office [in English].

2. Council on Governmental Relations. (1996). Review of University-Industry Research Relationships. Washington, DC: CGR [in English].

3. De la Garza, G. F. (1997). Team up: Higher education - business partnerships in North America: Understanding the differences (Working Paper No. 7). New York, NY: Ford Foundation [in English].

4. Eurich, N. P. (1985). Corporate classrooms: The learning business. Princeton, N.J.: Carnegie Foundation for the Advancement of Teaching [in English].

5. Fenwick, D. C. (1986). Guide to campusbusiness linkage programs: education and business prospering together. New York: Macmillan [in English].

6.Hasselmo, N. (2001). Working together, creating knowledge: The university-industry research collabora-
10. Smith H. C. Corporate/College Partnerships and Their Impact on Corporations and Institutions of Higher Education : A Higher Education Perspective : A dissertation submitted in partial fulfillment of the requirements for the degree of Doctor of Education / Heather C. Smith. - Johnson \& Wales University, 1999. - 130 p.

tion initiative. Retrieved from: http://www.bhef.com/sites/g/files/g829556/f/report_2001 _working_together.pdf[in English].

7. Powers, D. R., Powers, M. F., Betz, F., \& Aslanian, C. B. (1988). Higher education in partnership with industry. San Francisco: Jossey-Bass [in English].

8. Kerr, C. (1994). Higher education cannot escape history: Issues for the twenty-first century. Albany, N.Y.: State University of New York Press [in English].

9. Ohiienko, O. I. (2008). Tendentsii rozvytku osvity doroslykh u skandynavskykh krainakh [Trends in adult education in the Scandinavian countries]. Sumy: Ellada-S [in Ukrainian].

10. Smith, H. C. (1999). Corporate / college partnerships and their impact on corporations and institutions of higher education: A higher education perspective. Doctor's thesis. Providence, Rhode Island: Johnson \& Wales University [in English].

\section{Ірина Миколаӥвна Литовченко, кандидат педагогічних наук, доиент кафедри англійської мови технічного спрямування №2, Національний технічний університет України «Київський політехнічний інститут», пр-т Перемоги, 37, м. Київ, Украӥна}

\section{СТАНОВЛЕННЯ ІНСТИТУТУ СОЦАЛЬНОГО ПАРТНЕРСТВА ЯК ФАКТОРУ ЕФЕКТИВНОГО РОЗВИТКУ КОРПОРАТИВНОЇ ОСВІТИ У США}

Співпраця університетів з промисловою галуззю у Сполучених Штатах Америки триває понад століття, проте саме з розвитком глобальної економіки знань ця співпраця набула нових масштабів і проявів. Дослідницькі університети, бізнесові структури та уряд країни працюють над спільними новаторськими ініціативами зі створення й розвитку нових прогресивних форм партнерства між освітою та бізнесом, тим самим сприяючи потужному розвитку знань, усуненню суперечностей між освітньою галуззю та ринком праці, розв'язанню складних соціальних проблем, прискоренню економічного зростання країни. Метою статті є аналіз становлення інституту соціального партнерства як фактору ефективного розвитку корпоративної освіти у США, виявлення форм та механізмів його реалізації. 3 методологічної точки зору в основу дослідження покладено міждисциплінарний та системний підходи. Тому, ми використовували комплекс взаємопов'язаних методів дослідження: компаративний, структурний, системно-функціональний аналіз, порівняння та узагальнення, що $є$ необхідними для вивчення праць науковців, ділової літератури, офіційних і нормативних документів, статистичних даних. Результати здійсненого дослідження свідчать, що соціальне партнерство між бізнесом та освітою виникло як засіб вирішення суперечностей між освітою та ринком праці в умовах швидкого розвитку науки й технологій, змін у сфері зайнятості та необхідності підтримки конкурентоспроможності підприємств та держави в цілому. Активна державна підтримка сприяла створенню й потужному розвитку інституту соціального партнерства, різноманіття форм та механізмів реалізації якого сприяють модернізації корпоративної освіти у США, створенню нових знань, поширенню технологій, розробці нових продуктів і послуг.

Ключові слова: соціальне партнерство між промисловістю та закладами вищої освіти, форми соціального партнерства, заклади вищої освіти, промисловий сектор, корпоративна освіта у США. 
Ирина Николаевна Литовченко,

кандидат педагогических наук, дочент кафедры английского языка технического направления №2, Национальный технический университет Украинь «Киевский политехнический институт», пр-т Победы, 37, г. Киев, Украина

\section{СТАНОВЛЕНИЕ ИНСТИТУТА СОЦИАЛЬНОГО ПАРТНЕРСТВА КАК ФАКТОРА ЭФФЕКТИВНОГО РАЗВИТИЯ КОРПОРАТИВНОГО ОБРАЗОВАНИЯ В США}

Сотрудничество университетов с промышленной отраслью в Соединенных Штатах Америки продолжается более века, однако именно с развитием глобальной экономики знаний это сотрудничество приобрело новые масштабы и проявления. Исследовательские университеты, бизнес-структуры и правительство страны работают над совместными новаторскими инициативами по созданию и развитию новых прогрессивных форм партнерства между образованием и бизнесом, тем самым способствуя мощному развитию знаний, устранению противоречий между образовательной отраслью и рынком труда, решению сложных социальных проблем, ускорению экономического роста страны. Целью статьи является анализ становления института социального партнерства как фактора эффективного развития корпоративного образования в США, выявления форм и механизмов его реализации. С методологической точки зрения в основу исследования положены междисциплинарный и системный подходы. Поэтому мы использовали комплекс взаимосвязанных методов исследования: компаративный, структурный, системно-функциональный анализ, сравнение и обобщение, необходимые для изучения трудов ученых, деловой литературы, официальных и нормативных документов, статистических данных. Результаты проведенного исследования свидетельствуют, что социальное партнерство между бизнесом и образованием возникло как средство разрешения противоречий между образованием и рынком труда в условиях быстрого развития науки и технологий, изменений в сфере занятости и необходимости поддержания конкурентоспособности предприятий и государства в целом. Активная государственная поддержка способствовала созданию и развитию института социального партнерства, многообразие форм и механизмов реализации которого способствует модернизации корпоративного образования в США, созданию новых знаний, распространению технологий, разработке новых продуктов и услуг.

Ключевые слова: социальное партнерство между промышленностью и вузами, формы социального партнерства, учреждения высшего образования, промышленный сектор, корпоративное образование в США.

Рецензент: д. пед. н., проф. О. І. Огієнко

Подано до редакиії 18.10.2016

UDC: $378.141 .+81.28+811.114$

PhD (Candidate of Pedagogical Sciences) professor, Head of Foreign Langitana Bodnar, Odessa Institute of Trade and Economics of Kyiv National University of Trade and Economics, 6, $25^{\text {th }}$ Chapaiev Division Str., Odesa, Ukraine

\section{THE EDUCATIONAL PARADIGM SHIFT FOR STUDENT-CENTRED LEARNING IN THE PROCESS OF GLOBALISATION}

The article deals with the problem of the educational paradigm shift from the teacher-centred conception to the studentcentred learning conception. The notion of "student-centred learning" has been under study. The student-centred learning conception has been analyzed. Strategies of self-directed study of a foreign language have been investigated; the autonomy levels have been specified; the most effective methods and techniques which are used in the student-centred learning have been singled out. The project work as one of the student-centred learning technique has been accentuated on.

Keywords: student-centred learning, non-linguistic students, foreign languages, strategies of self-directed study, project work.

Social-economic and political changes, which take place in Ukraine, and the following increase of the role of a foreign language as a means of communication in the modern world arise new aims in the educational sphere to prepare professionally motivated specialists who master foreign languages at the internationally recognised level (e.g, levels PET, KET, FCE, TOEFL, BULATS), capable of autonomous improving of foreign language skills after graduation. In this connection, there is a need to reorient the educational process at the students' autonomy development in mastering foreign languages.

Despite the fact that lately the topic of autonomous learning of foreign languages has been in the center of Ukrainian and foreign scholars' attention (I. Bim, 